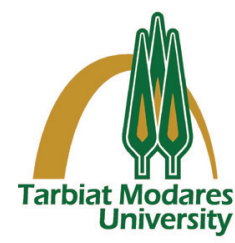

\title{
Epidemiological and Clinical Characteristics of Inactive Carriers of Hepatitis B Virus: A Descriptive Cross- Sectional Study in Burkina Faso
}

\section{ART I CLE INFO}

Article Type

Original Research

Authors

Eric Nagaonlé Somé, $P h D^{1^{*}}$

Alice Nanelin Guingané, $M P h^{2}$

Issaka Zongo, , $P h D^{1}$

Mahamado Lamine OUEDRAOGO, MD $^{2}$

Maxime Drabo, $P h D^{1}$

Roger Sombié, MD²

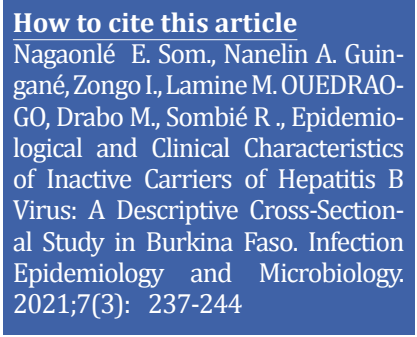

${ }^{1}$ Institut de Recherche en Sciences de la Santé (IRSS), Biomedical and public health department, Ouagadougou, Burkina Faso

${ }^{2}$ University Joseph Ki-Zerbo, UFR/ SdS, gastro-enterology department

\section{* Correspondence}

Address: 10 BP 250 Ouagadougou 10 Burkina Faso

Phone: +22670751333

eric.some@gmail.com

\section{A B S T R A C T}

Backgrounds: This study aimed to describe the epidemiological and clinical characteristics of inactive HBV chronic carriers at the gastroenterology department of the university teaching hospital Yalgado Ouedraogo.

Materials \& Methods: This descriptive cross-sectional study was conducted from January 1, 2007 to December 31, 2014 by employing a prospective data collection method. It was a census of all cases meeting the eligibility criteria. All patients with chronic viral hepatitis B (VHB) and $\geq 15$ years of age and presenting the following signs were included in this study: positive result on hepatitis $B$ surface antigen test for at least 6 months, normal levels of alanine amino-transferase for at least one year, positive anti-HBe antibodies, negative $\mathrm{HBeAg}$, and viral DNA $<20,000 \mathrm{IU} / \mathrm{mL}$.

Findings: The mean age of patients was 35 years, and the mean duration of HBsAg carriage was 6 years. The physical examination was normal in all participants. Ultrasound exam was normal in $150(92.6 \%)$ participants and showed a fatty liver in 12 (7.4\%) participants. Overall $4.4 \%$ of participants developed severe fibrosis, and no patient developed cirrhosis. The main indications for drug treatment included the existence of a family history of hepatocellular carcinoma (36.7\%), the presence of active hepatitis (33.3\%), and the progression of the fibrosis (30\%).

Conclusion: This study confirms the importance of close follow up of HBV-infected patients to dramatically reduce the risk of developing complications such as cirrhosis or hepatocellular carcinoma.

Keywords: Hepatitis B infection; HBeAg negative; Inactive Carriers; Sub Saharan Africa CITATION LINKS

[1] Revill PA, Penicaud C, Brechot C, Zoulim F. Meeting the challenge of ... [2] MacLachlan JH, Cowie BC. Hepatitis B virus .... [3] Vallet-Pichard A, Pol S. Hepatitis B virus treatment ... [4] Hu J, Protzer U, Siddiqui A. Revisiting hepatitis B virus: Challenges of ... [5] Anderson RT, Lim SG, Mishra P, Josephson F, Donaldson E, Given B, et al. Challenges, considerations, and ... [6] Soriano V, Barreiro P, Cachay E, Kottilil S, Fernandez-Montero JV, de Mendoza C. Advances in hepatitis ... [7] Mavilia MG, Wu GY. Mechanisms and prevention of vertical transmission in ... [8] Spearman C, Afihene M, Ally R, Apica B, Awuku Y, Cunha L, et al. Viral hepatitis in ... [9] Keane E, Funk A, Shimakawa Y. Systematic review with meta-analysis: The risk of ... [10] Breakwell L, Tevi-Benissan C, Childs L, Mihigo R, Tohme T. The status of ... [11] Meda N, Tuaillon E, Kania D, Tiendrebeogo A, Pisoni A, Zida S, et al. Hepatitis B and ... [12] European Association for the Study of the Liver. EASL 2017 clinical ... [13] Magalhaes MJ, Pedroto I. Hepatitis B virus inactive carriers: Which follow-up strategy? GE Port J Gastroenterol. 2015;22(2):47-51. [14] Mandé AR. Le cancer primitif du foie: Aspects épidémiologiques ... [15] M'Bengue AK, Doumbia M, Denoman SR, Ouattara DN, Adoubi I, Pineau P. A major ... [16] Amougou MA, Noah DN, Moundipa PF, Pineau P, Njouom R. A prominent ... [17] Khelifa F, Thibault V. Characteristics of hepatitis B viral ... [18] Kim WR. Epidemiology of hepatitis B in the ... [19] Zarski JP, Marcellin P, Leroy V, Trepo C, Samuel D, Ganne-Carrie N, et al. Characteristics of ... [20] Mak D, Babb de Villiers C, Chasela C, Urban MI, Kramvis A. Analysis of ... [21] Kadende P, Engels D, Ndoricimpa J, Ndabaneze E, Habonimana D, Marerwa G, et al. Les ... [22] Bryere J, Dejardin O, Launay L, Colonna M, Grosclaude P, (Francim) elRfdrdc. Socio-économic ... [23] Sia R. Les hépatites virales chroniques au Centre hospitalier ... [24] Akinyemiju T, Abera S, Ahmed M, Alam N, Alemayohu MA, Allen C, et al. The burden .... [25] Jaquet A, Tchounga B, Tanon A, Bagny A, Ekouevi DK, Traore HA, et al. Etiology of ... [26] Jaquet A, Wandeler G, Nouaman M, Ekouevi DK, Tine J, Patassi A, et al. Alcohol use, viral hepatitis, and ... [27] Rotman Y, Brown TA, Hoofnagle JH. Evaluation of the ... [28] Samant H. Correlation of quantitative HbsAg with ... [29] Reddy KR, Beavers KL, Hammond SP, Lim JK, Falck-Ytter YT. American Gastroenterological Association I. American Gastroenterological Association Institute guideline on the prevention and treatment of ... [30] Villeneuve J-P, Desrochers M, Infante-Rivard C, Willems B, Raymond G, Bourcier M, et al. A long-term follow-up study of ...
Received: May 052021

Accepted: ApJune 15,2021

Published: July 20,202 


\section{Introduction}

Hepatitis $B$ refers to the inflammatory damages caused by the hepatitis $B$ virus (HBV) to the liver. HBV infection is a major public health problem due to i) the high frequency of the disease, as estimated by the World Health Organization (WHO), about a third of the world population, including more than 250 million people, are infected by the chronic form of the infection ${ }^{[1-2]}$; ii) the seriousness of conditions threatening patients' life in acute and fulminant form of the disease, in chronic form of hepatitis, the risk of death due to complications like cirrhosis or primary liver cancer is still actual in the long run ${ }^{[3-4]}$; and iii) therapeutic challenges despite significant progresses in the field ${ }^{[1,4-6]}$.

The age of acquisition of the infection influences the natural history of the disease. Actually, more than $90 \%$ of subjects infected at birth become chronic carriers, while only 5 to $10 \%$ of those infected in adulthood progress to chronic carriers ${ }^{[7-}$ 8]. The prevalence of HBV chronic carriers worldwide is less than $2 \%$ in developed countries, while it is around $7 \%$ in Southeast Asia and sub-Saharan African countries ${ }^{[9-10]}$. In Burkina Faso, it is estimated to be 9.1\% (95\% CI: 8.5-9.7) [11].

Chronic hepatitis B history includes five phases ${ }^{[12]}$. The first two phases are challenging, with respect to their therapeutic management, and are accompanied by an increased risk of progression to cirrhosis or primary liver cancer. Phase 3 , previously called as "inactive carrier", is a HBeAg-negative chronic HBV infection. Its characteristics include the presence of serum anti-HBeAg (anti-HBe) antibodies, undetectable or low levels of HBV DNA $(<2000 \mathrm{IU} / \mathrm{mL})$, and normal ALT according to traditional cut-off values (around 40 IU/L). Some patients in this phase, however, may have HBV DNA levels $>2,000 \mathrm{IU} / \mathrm{mL}$ (usually <20,000 IU/mL), accompanied by persistent normal ALT, minimal hepatic necro-inflammatory activity, and low fibrosis. If these patients remain in this phase, the risk of the disease progression into cirrhosis or hepatocellular carcinoma is low, but progression to $\mathrm{CHB}$, usually in HBeAg negative patients, may occur. The loss of HBsAg and/or seroconversion may occur spontaneously in 1 to $3 \%$ of cases per year. Typically, these patients may have low serum HBsAg levels ( $<1000 \mathrm{IU} / \mathrm{mL})$.

The HBeAg-negative patients could be categorized as chronic active hepatitis with negative hepatitis B e-antigen (HBeAg-) or pre-C mutant form and chronic inactive hepatitis or inactive carriers. Patients in Phase 3 require close monitoring because of the risk of viral reactivation ${ }^{[13]}$.

objectives: This study aimed to describe the epidemiological and clinical characteristics of inactive chronic carriers of HBV at the gastroenterology department of the university teaching hospital Yalgado Ouedraogo.

\section{Materials and Methods}

This descriptive cross-sectional study was conducted from January 1, 2007 to December 31,2014 by employing a prospective data collection method at the gastroenterology department of the university teaching hospital Yalgado Ouédraogo. It was a census of all cases meeting the eligibility criteria. Patients with chronic hepatitis B (CHB) and at least 15 years of age and presenting the following signs were included in this study: positive result on hepatitis B surface antigen (HBsAg) test for at least 6 months, normal levels of transaminases (ALT) for at least one year, positive anti-HBe antibodies, negative $\mathrm{HBeAg}$, and viral DNA $<20,000 \mathrm{IU} / \mathrm{mL}$.

The collected variables included sociodemographic characteristics, clinical and biological aspects, circumstances of 
diagnosis, nosocomial risk factors for HBV infection, and patients final status at the end of the study. Continuous variables were pooled as means and standard deviations, and categorical variables were pooled as frequencies and percentages. The obtained data were routine data, collected and used anonymously with strict respect for patient's confidentiality. The statistical analysis was run using Epi Info software Version 7 and Excel Microsoft Office 2010. Operational definitions: HBV chronic carrier: a subject with a positive result on HBsAg test for more than 6 months as well as a positive result on anti-HBc (total IgG) antibody test.

Chronic inactive carrier: a chronic hepatitis B carrier with ALT within the normal range and HBV-DNA less than $2000 \mathrm{IU} / \mathrm{mL}$. Duration of HBsAg carriage: this is the time interval between the date of $\mathrm{HbsAg}$ detection and the end of our study.

Delay before the first medical visit: this is the time elapsed (in years) between the HBsAg positive test and the date the subject was recruited in the cohort.

Quality of the follow-up: it is estimated by the number of viral load analyses. The quality of follow-up is deemed good when the patient undergoes one or two viral load assessmentsperyear.

\section{Findings}

A total of 1167 cases of chronic hepatitis B were registered, including 295 (25.3\%) inactive carriers. Among which 162 cases were included in this analysis because many patients' files had significant missing data. Sociodemographic characteristics

The mean age of the participants was 35 years, ranging from 18 to 63 years. Figure 1 displays the distribution of the participants according to the age groups. The sex ratio was 2.3, including $113(70 \%)$ men. The formal private and public professional sectors were the most represented occupations with 95 (58.6\%) participants. There were 108 $(66.7 \%)$ singles.

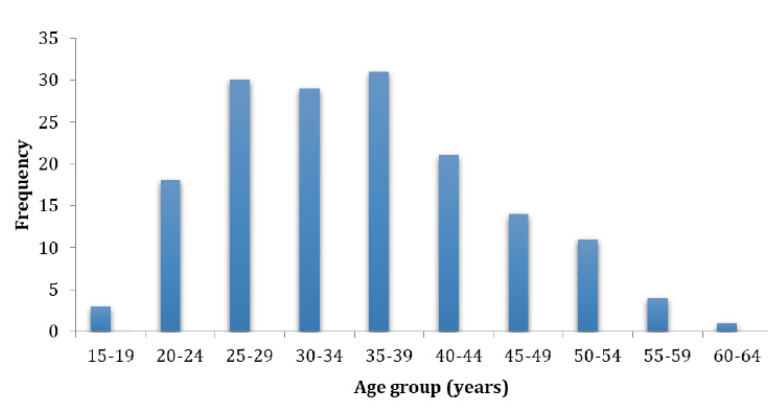

Figure 1) Distribution of patients according to the age groups

Clinical and biological aspects

The mean duration of HBsAg carriage was 6 years (ranging from 2 to 29 years). The circumstances of diagnosis are summarized in Table 1.

Routinehealth check-ups through occupational medical visits and blood donations accounted for $82.7 \%$ of screening opportunities. The mean duration between the diagnosis and the first medical visit was 13 months (ranging from 0 to 36 months). A family history of hepatitis $\mathrm{B}$ and alcohol consumption were found in 10 and $16.7 \%$ of cases, respectively. Nosocomial risks of HBV infection were found in $16.7 \%$ of patients (Table I). The distribution of patients according to the viral load is also summarized in Table 1.

The quality of medical follow up was deemed good because, on average, one viral load testing was performed per year per patient. However, significant disparities were identified according to the occupation sectors. The formal public or private sector employees, informal sector employees, and students or pupils performed an average of 2, 0.34 , and 0.47 viral load analyses per year per patient, respectively.

The physical examination was normal in all participants. Ultrasound exam was normal in 150 participants $(92.6 \%)$ and showed a fatty 
Table 1) Clinical characteristics of HBsAg+ patients according to the circumstances of diagnosis.

\begin{tabular}{|c|c|c|}
\hline & Frequencies & Percentages \\
\hline \multicolumn{3}{|l|}{ Circumstance of HBV infection diagnosis } \\
\hline Routine occupational checkup & 75 & 46.3 \\
\hline Blood donation & 59 & 36.4 \\
\hline Spontaneous screening & 12 & 7.4 \\
\hline Asthenia & 11 & 6.8 \\
\hline Jaundice & 3 & 1.9 \\
\hline Infectious syndrome & 2 & 1.2 \\
\hline Total & 162 & 100 \\
\hline \multicolumn{3}{|l|}{ Nosocomial risk factor for $\mathrm{HBV}$ infection } \\
\hline Surgical intervention & 9 & 33.3 \\
\hline Dental care & 7 & 26 \\
\hline Surgery + dental care & 5 & 18.5 \\
\hline Blood transfusion & 3 & 11.1 \\
\hline Surgical intervention + blood transfusion & 2 & 7.4 \\
\hline Endoscopy & 1 & 3.7 \\
\hline Total & 27 & 100 \\
\hline \multicolumn{3}{|l|}{ Final patient status at the end of the study } \\
\hline Inactive hepatitis B carrier & 128 & 80.5 \\
\hline Active hepatitis B carrier & 21 & 13.2 \\
\hline HBsAg negativation & 9 & 5.7 \\
\hline Hepatocellular carcinoma in cirrhosis & 1 & 0.6 \\
\hline Total & 159 & 100 \\
\hline \multicolumn{3}{|l|}{ Viral load (IU/mL) } \\
\hline Undetectable & 30 & 18.5 \\
\hline$<2000$ & 119 & 73.5 \\
\hline [2000-20000] & 13 & 8 \\
\hline Total & 162 & 100 \\
\hline \multicolumn{3}{|l|}{ Activity } \\
\hline A0 & 24 & 35.3 \\
\hline A 1 & 40 & 58.8 \\
\hline A 2 & 3 & 4.4 \\
\hline A 3 & 1 & 1.5 \\
\hline Total & 68 & 100 \\
\hline \multicolumn{3}{|l|}{ Fibrosis stage } \\
\hline F0 & 27 & 39.7 \\
\hline F 1 & 35 & 51.5 \\
\hline F 2 & 3 & 4.4 \\
\hline F 3 & 3 & 4.4 \\
\hline F 4 & 0 & 0 \\
\hline Total & 68 & 100 \\
\hline
\end{tabular}

liver in $12(7.4 \%)$ participants. The results of the blood tests related to the liver activity and liver fibrosis stages are presented in Table I. Overall, 39.7 and $51.5 \%$ of cases had no (F0) 
or a mild (F1) fibrosis stage, respectively. No patient had a cirrhosis (F4) (Table I). The mean HBsAg concentration (performed in 18 participants) was $4895 \mathrm{IU} / \mathrm{mL}$ (ranging from 125 to $17,895 \mathrm{IU} / \mathrm{mL}$ ). The concordance between the HBsAg concentrations and the viral loads are presented in Table 2 .

Hepatitis C and D as well as HIV tests were negative in all participants. Hepatitis $B$ tests were positive in $10.1 \%$ of the partners a $3.4 \%$ of the children.

Follow up and patients' status: Regarding the follow up, $98.1 \%$ of the participants were alive, and $1.9 \%$ were lost to follow-up at the end of the study. A total of $19.1 \%$ of the participants were under treatment, including 30 therapies with nucleoside analogues. The main indications for drug treatment included the existence of a family history of hepatocellular carcinoma (36.7\%), the presence of active hepatitis (33.3 $\%$ ), and the progression of the fibrosis (30 $\%)$. A 34-year-old patient underwent surgery for hepatocellular carcinoma in cirrhosis. The distribution of patients according to their HBV infection status at the end of the study is presented in Table I.

\section{Discussion}

Socio-demographic characteristics: The sex ratio was 2.3 in this study. Many authors have also reported this male predominance. Mandé (2014) ${ }^{[14]}$ in Burkina Faso, M'Bengue et al. (2015) ${ }^{[15]}$ in Ivory Coast, and Amougou (2016) ${ }^{[16]}$ in Central Africa found similar sex ratio. The mean age of the participants was 35 years, comparable to those in the studies by Khelifa (2009) ${ }^{[17]}$ in Algeria and Kim (2009) ${ }^{[18]}$ in the United States. In contrast, Zarsky et al.
(2006) ${ }^{[19]}$ in France found a mean age of 41.3 years. The predominance of early perinatal and horizontal transmission in Sub-Saharan Africa could explain this finding, knowing that most cases in the United States population were imported from Africa or Asia.

Civil servants and formal private sector employees were the most frequent participants (58.6\%) in this study, while many other studies have reported a higher prevalence among workers of informal sector and rural areas (farmers) ${ }^{[20-22]}$. This finding might be explained by further screening of these professional groups. Occupational medical visits, blood donations, and spontaneous check-ups are common habits of these groups. In addition, these groups are most able to pay for medical visits and other follow-up investigations.

Risk factors of the disease were found in the history of $16.7 \%$ of the participants. Sia (2009) ${ }^{[23]}$ in Burkina Faso noted a similar result with a frequency of $14.32 \%$. On the other hand, Zarsky (2006) ${ }^{[19]}$ reported frequencies of 35.7 and 36.5\% in France and Asia, respectively, which are higher than ours. Alcohol consumption was also found in $16.7 \%$ of the cases in this study versus $37.3 \%$ of the cases ${ }^{[18]}$ in the United States. Alcohol is believed to be the main cause of liver disease in developed countries [24]. In our context, it comes after the viral causes. Alcohol is a risk factor for the progression to fibrosis when consumption reaches $50 \mathrm{~g}$ or more per day ${ }^{[25-26]}$. Cytokines could be pathogenic factors contributing to the progression of the disease on an alcoholic liver ${ }^{[27]}$. Due to the increased alcohol-induced permeability of the intestine, high levels of peripheral cytokines are probably correlated

Table 2) Distribution of patients according to the viral loads and the HBsAg concentrations

\begin{tabular}{cccccc}
\hline \multirow{2}{*}{ HBsAg Concentration } & \multicolumn{3}{c}{ Viral Loads } & \multirow{2}{*}{ Total } \\
\cline { 2 - 5 } & Undetectable & $<2000$ & [2000-20000] & 3 \\
\hline$<1000$ & 3 & 0 & 0 & 15 \\
\hline$\geq 1000$ & 1 & 14 & 0 & 18 \\
\hline Total & 4 & 14 & 0 & 3 \\
\hline
\end{tabular}


with elevated levels of liver cytokines as a result of increased concentration of endotoxins in the blood. Therefore, quantification of alcohol consumption must be systematic and regular in patients infected with HBV.

HBV screening was performed incidentally for the majority of cases during a routine check-up visit (46.3\%) or blood donation (36.4\%). In contrast, the detection of HBV during an evocative symptomatology for asthenia, jaundice, and infectious syndrome was rare with frequencies of $6.8,1.9$, and $1.2 \%$, respectively. Sia ${ }^{[23]}$ in Burkina Faso in 2009 found similar statistics.

All three patients with HBs antigenemia < $1000 \mathrm{IU} / \mathrm{mL}$ had an undetectable viral load (100\%); while among the 15 patients with HBs antigenemia > $1000 \mathrm{IU} / \mathrm{mL}$, the viral load was undetectable only in one patient (6.7\%). Although controversial, a correlation would exist between the viral load and HBS antigenemia ${ }^{[28]}$. In this hypothesis, HBsAg quantification could be an interesting followup analysis for HBV-infected patients as a replacement for viral load testing which is too expensive and too complicated to implement; it could also help patients save money by reducing the number of viral load assessments in contexts where patients have to pay out of their own pocket. In the literature, a low risk of viral reactivation (annual incidence $<1.1 \%$ ) has been reported in HBV inactive carriers with HBs antigenemia < $1000 \mathrm{IU} / \mathrm{mL}^{[29]}$.

At the end of the study, $80.5 \%$ of patients were still inactive carrier, and $5.7 \%$ of patients were HBsAg negative. Some complications such as viral reactivation $(13.2 \%)$ and primary liver cancer were observed in a cirrhotic patient (0.6\%). Villeneuve et al. (1994) ${ }^{[30]}$ in Canada found a result close to ours with a frequency of $0.4 \%$ for cirrhosis. Asian studies have shown that HBV chronic carriers with negative HBeAg, viral load of $<2000 \mathrm{IU} / \mathrm{mL}$, normal ALT concentration, and HBs antigenemia $<1000$ IU / $\mathrm{mL}$ are at lower risk of developing cirrhosis or hepatocellular carcinoma compared to patients with HBs antigenemia > $1000 \mathrm{IU} / \mathrm{mL}$; this latter group of patients may have an indication for treatment ${ }^{[29]}$. Another important aspect of HBV inactive carriers is the high risk of viral reactivation in case of immunosuppressive therapy. It is therefore strongly recommended to initiate preventive antiviral treatment in any inactive carrier with detectable HBV DNA during any immunosuppressive treatment for up to 6 months after the end of the treatment. Limitations of the study: This study was performed by employing a prospective routine data collection method. Thus, additional biological and paraclinical analyses were not carried out by the participants for economic reasons. Since the participants were all asymptomatic, a significant number of missed visits were recorded. Therefore, it is believed that the description given in this work does not represent the whole reality of the cohort. However, what was observed in this work gave us a fairly objective picture of the epidemiological profile of CHB inactive carriers who are regularly monitored.

\section{Conclusion}

Over an eight-year follow-up period, $4.4 \%$ of the participants developed severe fibrosis, and no patient developed cirrhosis. of 162 participants, $98.1 \%$ were alive, and $1.9 \%$ were lost to follow-up. This study confirms the importance of close follow up of HBV-infected patients to dramatically reduce the risk of developing complications such as cirrhosis or hepatocellular carcinoma.

Acknowledgments: We are much grateful to the staff of the gastro-enterology department who contributed greatly to and facilitated the data collection. We want also to thank the administration of the university teaching hospital Yalgado Ouedraogo who provided all permission to make possible the data collection. Ethical permission: This study was 
implemented in the context of a medical doctorate thesis. Data collection forms were anonymised. The study obtained the required authorizations from the hospital management team. It was a prospective study collecting the required data from routine data of the gastroenterology unit. The student in charge of data collection was briefed on how to maintain confidentiality while collecting data from the source documents.

Conflicts of interests: The authors declare no conflict of interest.

Authors' contribution: Conceptualization: MLO, RS,; Data curation and formal analysis: MLO, ENS, RS,; Investigation: MLO,; Methodology and project administration: MLO, ENS, ANG, IZ, MD, RS,; Supervision: RS; Validation: ENS, ANG, IZ, MD, RS,; Writing of original draft: ENS,; Writing, reviewing, and editing: MLO, ENS, ANG, IZ, MD, RS.

Fundings: This research did not receive any specific grant from funding agencies in the public, commercial, or not-for-profit sectors. Consent to participate: Not applicable. The data were retrospectively collected from patients files.

\section{References}

1. Revill PA, Penicaud C, Brechot C, Zoulim F. Meeting the challenge of eliminating chronic hepatitis B infection. Genes. 2019;10(4):260.

2. MacLachlan JH, Cowie BC. Hepatitis B virus epidemiology. Cold Spring Harb Perspect Med. 2015;5(5):a021410.

3. Vallet-Pichard A, Pol S. Hepatitis B virus treatment beyond the guidelines: Special populations and consideration of treatment withdrawal. Ther Adv Gastroenterol. 2014;7(4):148 -55.

4. $\mathrm{Hu}$ J, Protzer U, Siddiqui A. Revisiting hepatitis B virus: Challenges of curative therapies. J Virol. 2019;93(20):e01032-19.

5. Anderson RT, Lim SG, Mishra P, Josephson F, Donaldson E, Given B, et al. Challenges, considerations, and principles to guide trials of combination therapies for chronic hepatitis B virus. Gastroenterology. 2019;156(3):529-33.

6. Soriano V, Barreiro P, Cachay E, Kottilil S, Fernandez-Montero JV, de Mendoza C. Advances in hepatitis B therapeutics. Ther AdvInfectDis.2020;7:2049936120965027.

7. Mavilia MG, Wu GY. Mechanisms and prevention of vertical transmission in chronic viral hepatitis. J Clin Transl Hepatol. 2017;5(2):119-29.

8. Spearman C, Afihene M, Ally R, Apica B, Awuku Y, Cunha L, et al. Viral hepatitis in sub-Saharan Africa 1: Hepatitis B in sub-Saharan Africa: Strategies to achieve the 2030 elimination targets. Lancet. 2017;2(12):900-9.

9. Keane E, Funk A, Shimakawa Y. Systematic review with meta-analysis: The risk of mother-to-child transmission of hepatitis B virus infection in subSaharan Africa. Aliment Pharmacol Ther. 2016;44(10):1005-17.

10. Breakwell L, Tevi-Benissan C, Childs L, Mihigo R, Tohme T. The status of hepatitis B control in the African region. Pan Afr Med J. 2017;27(Supp 3):17.

11. Meda N, Tuaillon E, Kania D, Tiendrebeogo A, Pisoni A, Zida S, et al. Hepatitis B and C virus seroprevalence, Burkina Faso: A crosssectional study. Bull World Health Organ. 2018;96(11):750-9.

12. European Association for the Study of the Liver. EASL 2017 clinical practice guidelines on the management of hepatitis $B$ virus infection. J hepatol. 2017;67(2):370-98.

13. Magalhaes MJ, Pedroto I. Hepatitis B virus inactive carriers: Which follow-up strategy? GE Port J Gastroenterol. 2015;22(2):47-51.

14. Mandé AR. Le cancer primitif du foie: Aspects épidémiologiques, diagnostiques, thérapeutiques et évolutifs au centre hospitalier universitaire Yalgado Ouédraogo. [Thèse de doctorat en 
médecine]. UFS/SDS Section médecine Université de Ouagadougou. 2014;246:159.

15. M'Bengue AK, Doumbia M, Denoman SR, Ouattara DN, Adoubi I, Pineau P. A major shift of viral and nutritional risk factors affects the hepatocellular carcinoma risk among Ivorian patients: A preliminary report. Infect Agents Cancer. 2015;10(1):18.

16. Amougou MA, Noah DN, Moundipa PF, Pineau P, Njouom R. A prominent role of hepatitis $\mathrm{D}$ virus in liver cancers documented in Central Africa. BMC Infect Dis. 2016;16(1):647.

17. Khelifa F, Thibault V. Characteristics of hepatitis B viral strains in chronic carrier patients from North-East Algeria. Pathol Biol. 2009;57(1):107-13.

18. Kim WR. Epidemiology of hepatitis B in the United States. Hepatology. 2009;49(5 Suppl):S28-34.

19. ZarskiJP,Marcellin P,LeroyV,TrepoC,Samuel D, Ganne-Carrie N, et al. Characteristics of patients with chronic hepatitis B in France: Predominant frequency of $\mathrm{HBe}$ antigen negative cases. J Hepatol. 2006;45(3):35560.

20. Mak D, Babb de Villiers C, Chasela C, Urban MI, Kramvis A. Analysis of risk factors associated with hepatocellular carcinoma in black South Africans: 2000-2012. PloS One. 2018;13(5):e0196057.

21. Kadende P, Engels D, Ndoricimpa J, Ndabaneze E, Habonimana D, Marerwa $\mathrm{G}$, et al. Les cancers digestifs au Burundi: Premiers résultats d'une enquête menée à Bujumbura. Méd Afr Noire. 1990;37(10):552-61.

22. Bryere J, Dejardin O, Launay L, Colonna M, Grosclaude P, (Francim) elRfdrdc. Socio-économic environment and cancer incidence in France. BEH. 2017;4:68 - 77.

23. Sia R. Les hépatites virales chroniques au Centre hospitalier Universitaire Yalgado
Ouédraogo: Aspects épidémiologiques, diagnostiques, thérapeutiques et évolutifs. Thèse de Ouagadougou (PA). Université de Ouagadougou; 2009, 1-77.

24. Akinyemiju T, Abera S, Ahmed M, Alam N, Alemayohu MA, Allen $\mathrm{C}$, et al. The burden of primary liver cancer and underlying etiologies from 1990 to 2015 at the global, regional, and national Level. JAMA Oncology. 2017;3(12):1683-91.

25. Jaquet A, Tchounga B, Tanon A, Bagny A, Ekouevi DK, Traore HA, et al. Etiology of hepatocellular carcinoma in West Africa, a case-control study. Int J cancer. 2018;143(4):869-77.

26. Jaquet $A$, Wandeler G, Nouaman M, Ekouevi DK, Tine J, Patassi A, et al. Alcohol use, viral hepatitis, and liver fibrosis among HIV-positive persons in West Africa: A cross-sectional study. J Int AIDS Soc. 2017;20(1):21424.

27. Rotman Y, Brown TA, Hoofnagle JH. Evaluation of the patient with hepatitis B. Hepatology. 2009;49(5 Suppl):S22-7.

28. Samant H. Correlation of quantitative HbsAg with quantitative HBV DNA in different phases of chronic hepatitis B (CHB) patients. J Liver Res Disord Ther. 2016;1(3).

29. Reddy KR, Beavers KL, Hammond SP, Lim JK, Falck-Ytter YT. American Gastroenterological Association I. American Gastroenterological Association Institute guideline on the prevention and treatment of hepatitis B virus reactivation during immunosuppressive drug therapy. Gastroenterology. 2015;148(1):215-9. 30. Villeneuve J-P, Desrochers $M$, InfanteRivard C, Willems B, Raymond G, Bourcier $\mathrm{M}$, et al. A long-term follow-up study of asymptomatic hepatitis B surface antigen-Positive carriers in montreal. Gastroenterology. 1994;106(4):1000-5. 